\title{
Techno-economic-enviro optimization analysis of diesel/PV/wind with pumped hydro storage for Mentawai Island microgrid
}

\author{
Syafii $^{1}$, Wati $^{2}$, Rahmad Fahreza ${ }^{3}$ \\ ${ }^{1,3}$ Electrical Engineering Department, Faculty of Engineering, Universitas Andalas, Padang, Indonesia \\ ${ }^{2}$ Accounting Education Department, STKIP PGRI Sumatera Barat, Indonesia
}

\begin{tabular}{l}
\hline Article Info \\
\hline Article history: \\
Received Jun 25, 2021 \\
Revised Aug 20, 2021 \\
Accepted Aug 27, 2021 \\
\hline
\end{tabular}

Keywords:

Hybrid diesel/PV/wind

Microgrid system

Pumped hydro storage

Techno-economic-enviro

\begin{abstract}
This paper presents a techno-economic analysis and environment assessment of hybrid photovoltaic (PV), wind turbine (WT), and diesel genset (DG) with pumped hydro storage (PHS) for a rural microgrid system. The analysis is carried out for a case study with Mentawai community load demand of 165.44 $\mathrm{kWh}$ /day at a peak load of $20.46 \mathrm{~kW}$. The Homer simulation results show that there are eight feasible configurations, which the optimal hybrid system configuration to supply community load is the configuration with PV/DG/PHS. An optimal system has been achieved for the lowest NPC of Indonesian rupiah (IDR) 3,00 B consist of $15 \mathrm{kWp} \mathrm{PV} \mathrm{modules,} 1$ unit of PHS and a solar inverter with a size $25 \mathrm{~kW}$. The net present cost and payback period are in accordance with criteria for the economic feasibility analysis method of a project. However, the cost of energy is greater than the electrical utility tariff, but this value can be considered for applications in the remote island area. Therefore, the project still feasible to be implemented. Since the renewable fraction of the system is increased hence this proposed system will have the lowest carbon emission.
\end{abstract}

This is an open access article under the CC BY-SA license.

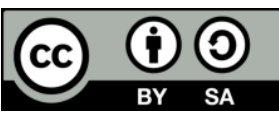

\section{Corresponding Author:}

Syafii

Electrical Engineering Department,

Engineering Faculty, Universitas Andalas

Limau Manis, Kec. Pauh, Kota Padang, Sumatera Barat 25175, Indonesia

Email: syafii@eng.unand.ac.id

\section{INTRODUCTION}

The decreasing availability of fossil energy resources and the increasing awareness of efforts to conserve the environment, has led researchers to keep thinking of looking for new renewable energy (NRE) alternatives by utilizing the potential of local resources. Among renewable energy sources, the integration of solar power generation is the most developed and reliable alternative [1]. The location of Indonesia which is on the equator theoretically will receives a significant amount of solar radiation throughout the year [2]. This condition is very advantage for establishing solar energy to electrify and decarbonise rural communities in Indonesia as a tropical country. Solar, wind, and microhydro power plants have also become priority sources of renewable energy that will be developed in Indonesia to achieve the NRE target of $23 \%$ by 2025 and $31 \%$ by 2050 [3]. Regarding environment consideration, Indonesia has committed by 2030 to reduce $29 \%$ of carbon emissions as the agreement of united nations climate change conference held in Paris, 2015 [4]. The main advantage of solar and wind hybrid systems is that when the production of solar and wind power is used together can increase the system reliability [5]. 
Solar and wind energy are intermittent energy, meaning that energy unable to provide electricity 24 hours/day or continuously [6], [7]. To make intermittent energy fully reliable as a power supply for base load and to keep up with fluctuations in demand, the electricity generated must be stored to allow energy delivery on demand. Therefore, energy storage is essential for independent PV/wind power generation, and a solution to the intermittent problem of energy production. Integrating NRE power plants in load centers can reduce power losses and increase the voltage of the electrical network [8]. Apart from that, it is easy to maintain and operate but has a significant impact on reducing pollution and the greenhouse effect [9], [10]. Besides that, there are some disadvantages of using solar and wind energy, especially in terms of the relatively low output efficiency [11], [12]. Several factors affect the electrical power generated, such as the type of inverter used, the level of light intensity, the working temperature of the solar panels, and the storage system.

Energy storage technology research continues to develop accompanied by the use of sustainable renewable energy for remote areas. There are various energy storage technologies currently used in distributed generation based on renewable energy, such as batteries [13], gear [14], compressed air [15], supercapacitor [16], and pumped hydro [17]. Pumped water storage technique, which is the most widely used energy storage technology today, with more than 300 plants (more than $127 \mathrm{GW}$ ) installed worldwide [18]. Several previous researchers have focused on developing efficient, reliable, and economical energy control and management systems to solve the problem of integrating solar and hydro hybrid power plants on either islanded systems or existing conventional power systems. Mengi and Altas in 2015 conducted a study on the optimal hybrid generation control system to meet the demand for water supply in Bolivia using the hybrid optimization by genetic algorithm (HOGA) program [19]. After that, Dursun and Kilic have compared three different artificial intelligence (AI-based) power management control system strategies, in particular the effect on energy efficiency for standalone hybrid systems [20]. This system uses solar panels, wind turbines as well as proton exchange membrane fuel cells (PEMFC) as backup sources. The results suggest that power generation by a hybrid system is more reliable and cheaper than a single-source system alone.

A literature review article on energy storage technologies is provided in the references [21]. Among these technologies, rechargeable lead-acid batteries, especially those with deep dissipation rates, and high stability, are generally used in standalone renewable energy systems. Currently, batteries have become at the forefront of use as a storage medium for renewable energy generation. However, the battery has known limitations [22], such as high initial investment, relatively short life, possible environmental damage and explosions due to lead and sulfuric acid, and difficulties for maintenance in isolated areas. As an alternative to storage technology based on pumped water is the right choice. Based on economic studies pumped hydro energy storage technology is more economical than batteries for standalone applications [23].

The reduction in electricity subsidies and the introduction of incentives for the use of solar power plants led to increased development and construction of solar power plants above houses and buildings [24]. Solar and wind power plants in generating electricity are very dependent on weather conditions. To maintain the stability of the electricity supply, it is necessary to pair it with a storage system such as batteries or pumped water and also with other generators such as thermal generators. The choice of solar, wind and hydropower plants have its own advantages when compared to other NRE generators, including easier and cheaper to integrate with existing electricity systems, can utilize existing land (reduce land investment costs), does not contain carbon emissions and maximally available in a tropical climate area [25]. But the unpredictability and random of sunlight and wind speed are still an obstacle to using this hybrid energy [26], [27]. Energy storage devices are generally used to smooth variations NRE generators output due to unpredictability resources [28]. This paper presents the utilization of hanseatic power solutions (HPS) as energy storage to solve the problem by using a power management control system from a solar-wind with hydro storage microgrid power system and a backup power from a diesel generator.

\section{RESEARCH METHOD}

\subsection{Load profile of Mentawai Island microgrid}

This study uses Peipei load data, Southwest Siberut, Mentawai Islands, and West Sumatra. Peipei Hamlet is traversed by the Peipei river which is $16 \mathrm{~km}$ long and $\pm 10 \mathrm{~m}$ wide. The solar pumped storage is placed in the lowest area in Peipei Hamlet. From the jetty to the sub-district office it descends, as well as from the upstream direction of the Pei-pei River to PHS it also decreases. The cross-section of the Peipei river which passes through Peipei Hamlet is very winding, indirectly it will slow down the speed of the water flow so that the river will quickly fill up if the rainfall is high. Based on this information, the authors assume that this location is suitable for case studies and that there is no need to build a tower to raise the upper reservoir because the location is a basin and hilly zone. The geographical location of the study area in Mentawai Island as show in Figure 1. The design of solar/wind with pumped hydro storage will be implemented for powered of Mentawai Island microgrid demand around $165.44 \mathrm{kWh}$ /day with peak load

Techno-economic-enviro optimization analysis of diesel/PV/wind with pumped hydro storage for ... (Syafii) 
$20.46 \mathrm{~kW}$ and load factor 0.34 as shown in Figure 2. The random variability is used $10 \%$ for day-to-day and $20 \%$ for timestep.

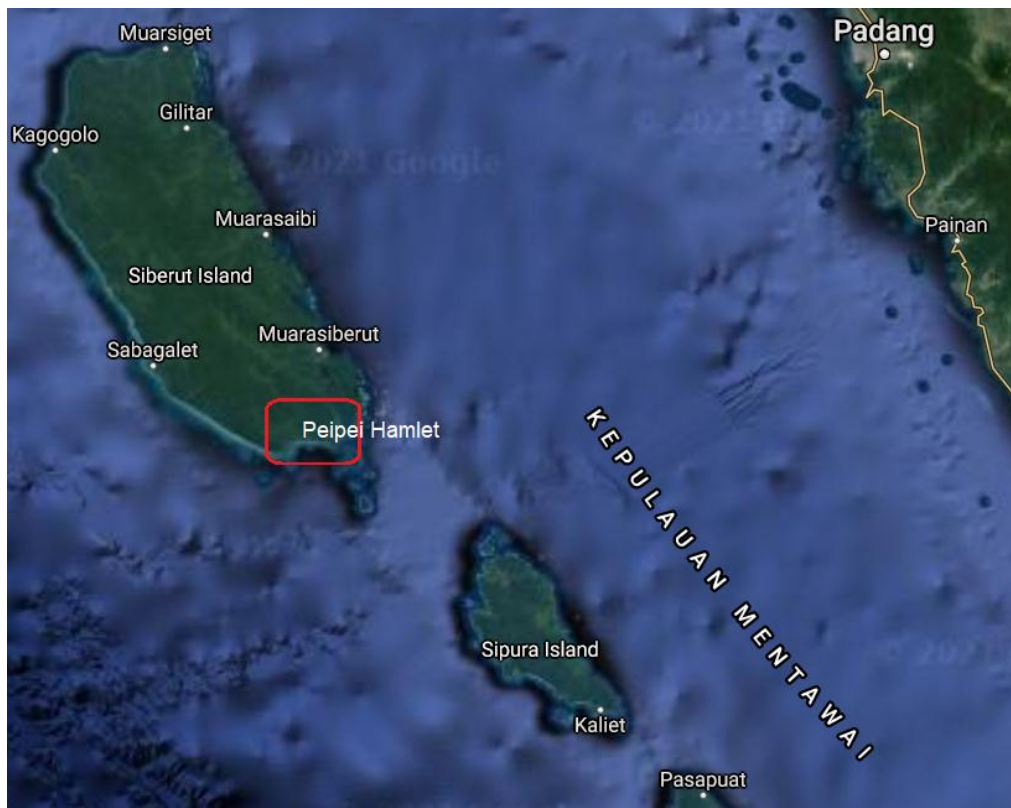

Figure 1. Geographical location of the study area in Mentawai Island, Indonesia

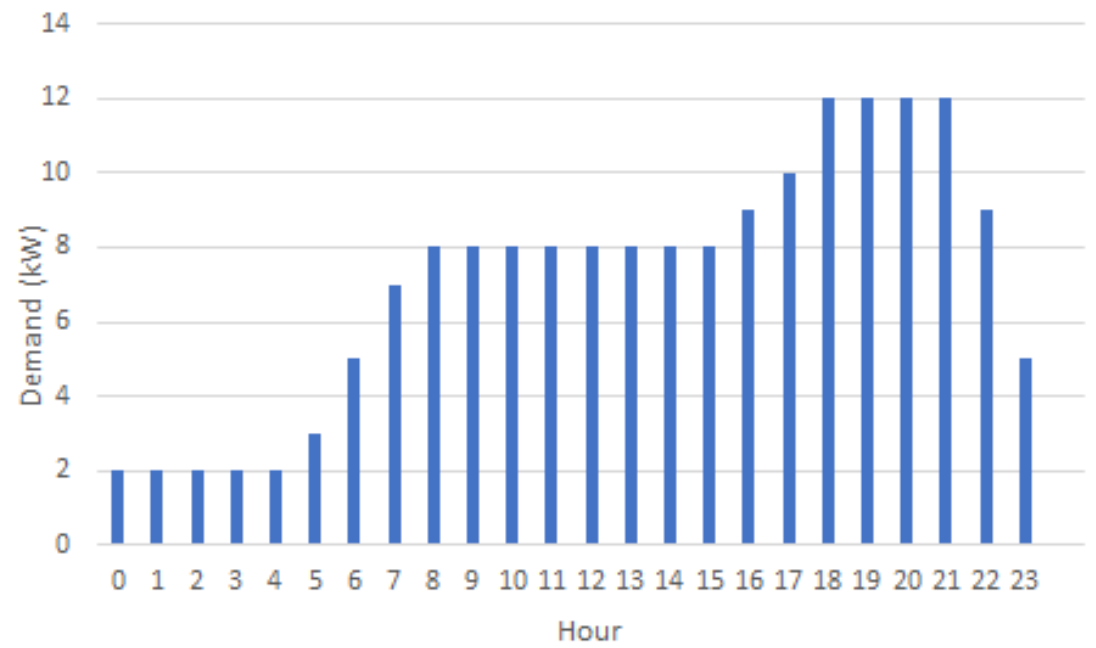

Figure 2. Daily load profile of Mentawai Island microgrid

\subsection{Solar and wind resources}

The amount of electrical energy produced by a solar power plant is mainly determined by the availability of sunlight, while wind power is based on the wind speed at the location where it is placed. The meteorological monthly data of solar radiation and wind speed are imported from NASA's website for the location of Peipei Hamlet, Siberut Island, Mentawai (1 $\left.{ }^{\circ} 25.6^{\prime} \mathrm{S}, 98^{\circ} 55.5^{\prime} \mathrm{E}\right)$ given in Table 1 . The average annual solar radiation received per day is $4,75 \mathrm{kWh} / \mathrm{m}^{2} /$ day and the average wind speed is $3.66 \mathrm{~m} / \mathrm{s}$.

These two weather parameters are used as input for Homer's software for analyzing the economic feasibility of PV/wind powered microgrid system in the Mentawai Islands. The wind speed and solar radiation profiles are close to the weather patterns in various remote islands in Indonesia. Therefore, the results of this study can become a consideration for the development of PV/wind with pumped hydro storage for Indonesia remote island applications. 
Table 1 . Monthly averaged radiation and wind speed

\begin{tabular}{cccc}
\hline Month & Clearness index & Radiation $\left(\mathrm{kWh} / \mathrm{m}^{2} / \mathrm{d}\right)$ & Wind speed $(\mathrm{m} / \mathrm{s})$ \\
\hline Jan & 0.46 & 4.79 & 4.34 \\
Feb & 0.50 & 5.28 & 4.05 \\
Mar & 0.48 & 5.05 & 3.41 \\
Apr & 0.49 & 4.97 & 2.98 \\
May & 0.52 & 5.04 & 3.15 \\
Jun & 0.52 & 4.84 & 3.38 \\
Jul & 0.50 & 4.64 & 3.80 \\
Aug & 0.46 & 4.59 & 4.02 \\
Sep & 0.43 & 4.52 & 3.93 \\
Oct & 0.44 & 4.59 & 3.36 \\
Nov & 0.41 & 4.24 & 3.44 \\
Dec & 0.44 & 4.50 & 4.09 \\
\hline
\end{tabular}

\subsection{System components}

The main components of the systems studied are PV systems, wind turbines, water-pumped storage, and converters. PHS is used as a storage system when the sun and wind are not available to be used to meet the load demands. The capacity of the PHS is designed to meet the load requirements with a water capacity of $7000 \mathrm{~m}^{3}$, with a reservoir height of $12 \mathrm{~m}$, assuming a hydro generator efficiency of $75 \%$. The capacity of electrical energy stored in PHS can be calculated using the following equation:

$\mathrm{Es}=9,81 \eta \mathrm{h} \mathrm{Vol} / 3600$

where; Es=stored energy $(\mathrm{kWh})$

$\eta=$ hydro generator efficiency $(\%)$

$\mathrm{h}=$ falling a height $(\mathrm{m})$

Vol=reservoir volume $\left(\mathrm{m}^{3}\right)$

While the output power of PHS depends on the rate of water discharge, as in the following equation:

$\mathrm{P}=9,81 \eta \mathrm{h} \mathrm{Q}$

where; $\mathrm{P}=$ power $(\mathrm{kW})$

$\mathrm{Q}=$ average flow $\left(\mathrm{m}^{3} / \mathrm{s}\right)$

The PHS was designed using $7000 \mathrm{~m}^{3}$ water stored on a $12 \mathrm{~m}$ upper reservoir which equals 171.68 $\mathrm{kWh}$ electrical energy stored. By using (1) and (2), the PHS energy and power output are obtained as shown in Table 2. The technical specification and financial data of the proposed Mentawai Island microgrid system are tabulated in Table 3. The individual system components in the system such as size, service life and cost are determined in detail. The pumped hydro storage PV system is designed consists of power circuit or electrical installation, water pipe installation and Arduino control circuits. The list of costs for installation and operation of PHS is shown in Table 3 as well as others system component.

Table 2. PHS store energy and output power

\begin{tabular}{cccc}
\hline $\mathrm{Q}(\mathrm{m} 3 / \mathrm{s})$ & Depletion time (hour) & Es $(\mathrm{kWh})$ & $\mathrm{P}(\mathrm{kW})$ \\
\hline 1,9444 & 1 & 171,68 & 171,68 \\
0,9722 & 2 & 171,68 & 85,84 \\
0,6481 & 3 & 171,68 & 57,23 \\
0,4861 & 4 & 171,68 & 42,92 \\
0,3889 & 5 & 171,68 & 34,34 \\
0,3241 & 6 & 171,68 & 28,61 \\
0,2778 & 7 & 171,68 & 24,53 \\
0,2431 & 8 & 171,68 & 21,46 \\
0,2160 & 9 & 171,68 & 19,08 \\
0,1944 & 10 & 171,68 & 17,17 \\
\hline
\end{tabular}

The schematic diagram of a PV/wind/diesel microgrid system integrated with PHS in the Homer pro V3.13 application to serve the load demand of $165.44 \mathrm{kWh} /$ day is shown in Figure 3 . The objective of Homer optimization is to identify a microgrid configuration which has low NPC and low CoE. The constraints be considered in Homer optimizasion process consist of PV derarting factor is $88 \%$ with $15.3 \%$ module efficiency, PHS assumed that the generator turbine acts a pump in the reserve case, so that the charging, and recharging current same. Initial PHS state of reservoir $100 \%$ and minimum until empty $0 \%$. WT used with capacity $3 \mathrm{~kW}$, with hub height $17 \mathrm{~m}$ and a converter efficiency $97.45 \%$. 
Table 3. Components costs in Homer simulation

\begin{tabular}{|c|c|}
\hline \multicolumn{2}{|l|}{ PV System } \\
\hline Sharp ND-250QCS $1 \mathrm{~kW}$ & IDR. $10,000,000$ \\
\hline Installing MCBs, busbars and fuses cost & IDR. $1,000,000$ \\
\hline Total cost & IDR. $11,000,000$ \\
\hline O\&M Cost per year ( $5 \%$ of PV Cost) & IDR. 500,000 \\
\hline \multicolumn{2}{|l|}{ WT } \\
\hline Generic Wind Turbine $3 \mathrm{~kW}$ & IDR. $12,000,000$ \\
\hline Replacement Cost & IDR. $3,000,000$ \\
\hline Total cost & IDR. $15,000,000$ \\
\hline O\&M Cost per year ( $10 \%$ of WT Cost) & IDR. $1,200,000$ \\
\hline \multicolumn{2}{|l|}{ Inverter } \\
\hline Solar Inverter Sinecxel $30 \mathrm{~kW}$ & IDR. 50,000,000 \\
\hline O\&M Cost & IDR. 0,0 \\
\hline Replacement Cost & IDR. $50,000,000$ \\
\hline \multicolumn{2}{|l|}{ Pumped Hydro Storage } \\
\hline Hydro Turbine Generator/Motor & IDR. $30,000,000$ \\
\hline Water Dam $7000 \mathrm{~m}^{3}$ and pipe installation & IDR. $70,000,000$ \\
\hline Replacement Cost & IDR. 50,000,000 \\
\hline O\&M Cost per year & IDR. 500,000 \\
\hline
\end{tabular}

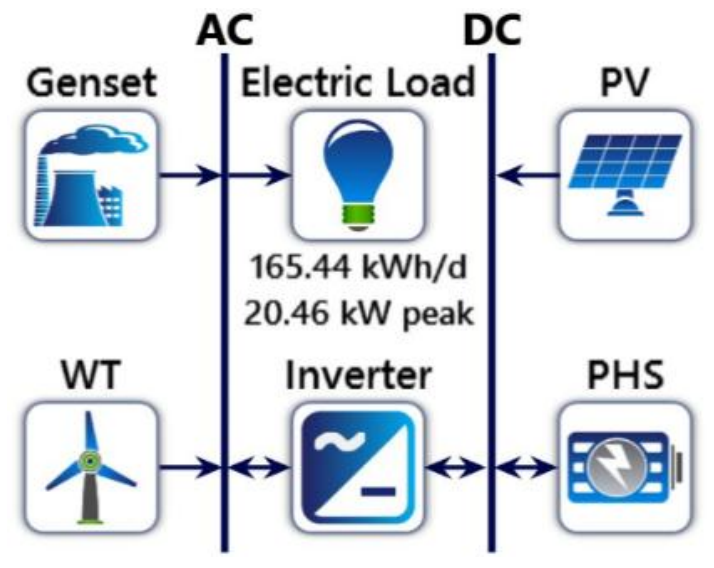

Figure 3. The main components of the microgrid system design

The output of the simulation results is in the form of an optimal system design model to be analyzed. Economic feasibility analysis uses three methods, namely, net present cost, payback period, and cost of energy. The net present cost calculated using the following expression:

$$
\mathrm{NPC}=\mathrm{CC}+\mathrm{RC}+\mathrm{O} \& \mathrm{M} \text { Cost }+\mathrm{FC}-\text { Salvage }
$$

where; $\mathrm{NPC}=$ net present cost (IDR)

$\mathrm{CC}=$ capital cost (IDR)

$\mathrm{RC}=$ replacement cost (IDR)

O\&M cost=operation and maintenance cost (IDR)

The payback period is the number of years of payback for the investment cost of a project. This payback period calculation is carried out to determine the financial risk to the project that will be carried out. The payback period value can be calculated using the following equation:

$$
\text { Payback Period=ICR/Inc } \text { year }_{\text {}}
$$

where; RIC=renewable investment costs (IDR)

Inc $_{\text {year }}=$ per year income (IDR)

Cost of energy (COE) is the average value of electrical energy per $\mathrm{kWh}$ produced by the system in a project. COE has criteria if it is less than the basic cost of providing electricity, then it is feasible to continue, if it is greater then it is not feasible to continue. The calculation of the COE value can be done using the following equation:

$$
\mathrm{CoE}=\mathrm{TAC} / \mathrm{kWh} \mathrm{T}_{\mathrm{Tot} \_ \text {Prod }}
$$

where; TAC=total annualized cost (IDR)

$\mathrm{kWh}_{\text {Tot_Prod }}=$ total $\mathrm{kWh}$ production $(\mathrm{kWh})$

\section{RESULTS AND DISCUSSION}

A comparative analysis of economic benefits for various configurations is given in Table 4. The optimized results with the smallest NPC and CoE were obtained in the configuration with PV, diesel genset, and PHS. Meanwhile, the wind turbine is less than optimal due to the low wind potential in the western region of Indonesia. Diesel generator integration has a greater influence on COE than PHS. Low annual NPC for PV+PHS (IDR 2,387) and high for base case i.e. microgrid with diesel generator only (IDR 3,134). This Homer simulation results use to determine the main component variables of PV modules, wind turbine with the pumped hydro storage system when operating. The optimal design configuration consists of $15 \mathrm{kWp}$ solar panels, $25 \mathrm{~kW}$ inverters and a pumped hydro storage unit with a nominal capacity of $171.44 \mathrm{kWh}$. The pumped hydro storage can cover the electrical energy demand during the solar module and wind turbines not produce energy. 
Table 4. Components costs in Homer simulation

\begin{tabular}{ccccc}
\hline Configuration & NPC (IDR) & CoE (IDR/kWh) & Operating cost (IDR) & Initial capital (IDR) \\
\hline PV/DG/PHS & $3.00 \mathrm{~B}$ & 2,387 & $125 \mathrm{M}$ & $407 \mathrm{M}$ \\
PV/WT/DG/PHS & $3.01 \mathrm{~B}$ & 2,395 & $124 \mathrm{M}$ & $419 \mathrm{M}$ \\
DG/PHS & $3.66 \mathrm{~B}$ & 2,908 & $164 \mathrm{M}$ & $242 \mathrm{M}$ \\
WT/DG/PHS & $3.68 \mathrm{~B}$ & 2,924 & $164 \mathrm{M}$ & $254 \mathrm{M}$ \\
Base Case (DG) & $3.94 \mathrm{~B}$ & 3,134 & $184 \mathrm{M}$ & $100 \mathrm{M}$ \\
WT/DG & $3.97 \mathrm{~B}$ & 3,157 & $185 \mathrm{M}$ & $112 \mathrm{M}$ \\
PV/DG & $4.07 \mathrm{~B}$ & 3,236 & $186 \mathrm{M}$ & $197 \mathrm{M}$ \\
PV/WT/DG & $4.10 \mathrm{~B}$ & 3,261 & $187 \mathrm{M}$ & $209 \mathrm{M}$ \\
\hline
\end{tabular}

The result in Table 4 also shows that, although the configuration with DG requires a minimum investment of $100 \mathrm{M}$, it has a large operational cost for diesel fuel. Meanwhile, the initial investment for the hybrid PV/DG/PHS system is $407 \mathrm{M}$, but the operating cost is the lowest at $125 \mathrm{M}$ per year, resulting in the lowest NPC and CoE. Thus, the most optimal configuration is obtained for the system with the lowest operational costs and is relatively independent of the size of the initial investment.

\subsection{Operational analysis}

The total energy production produced during the year from off-grid PV system with the pumped hydro storage system during operation to meet the daily electricity load demand of $20,653 \mathrm{kWh} / \mathrm{year}$. The total AC consumption of Mentawai Island microgrid is $60,386 \mathrm{kWh} /$ year. The results of this electrical energy production are assumed if PV works optimally with the support of sunny weather factors by the solar radiation index obtained from the NASA website. Pumped hydro storage simulation results also have incoming energy of $10,081 \mathrm{kWh} /$ year and energy output of $8,393 \mathrm{kWh} /$ year with losses of $1,941 \mathrm{kWh} /$ year. The working principle of pumped hydro storage is to drain the water from the upper reservoir when the load is peak and pump back the water from the lower reservoir when the load is low.

Energy scheduling of the optimal hybrid system for three days in July is shown in Figure 4. This figure shows the fulfillment of power generation demand which is divided by PV, PHS, and diesel systems. Wind turbine does not produce electricity due to low wind speed, while diesel is scheduled at night when PV does not produce electricity and PHS is not available enough. In addition, the PHS performance during the charging and discharging period is also demonstrated in the Figure 4.

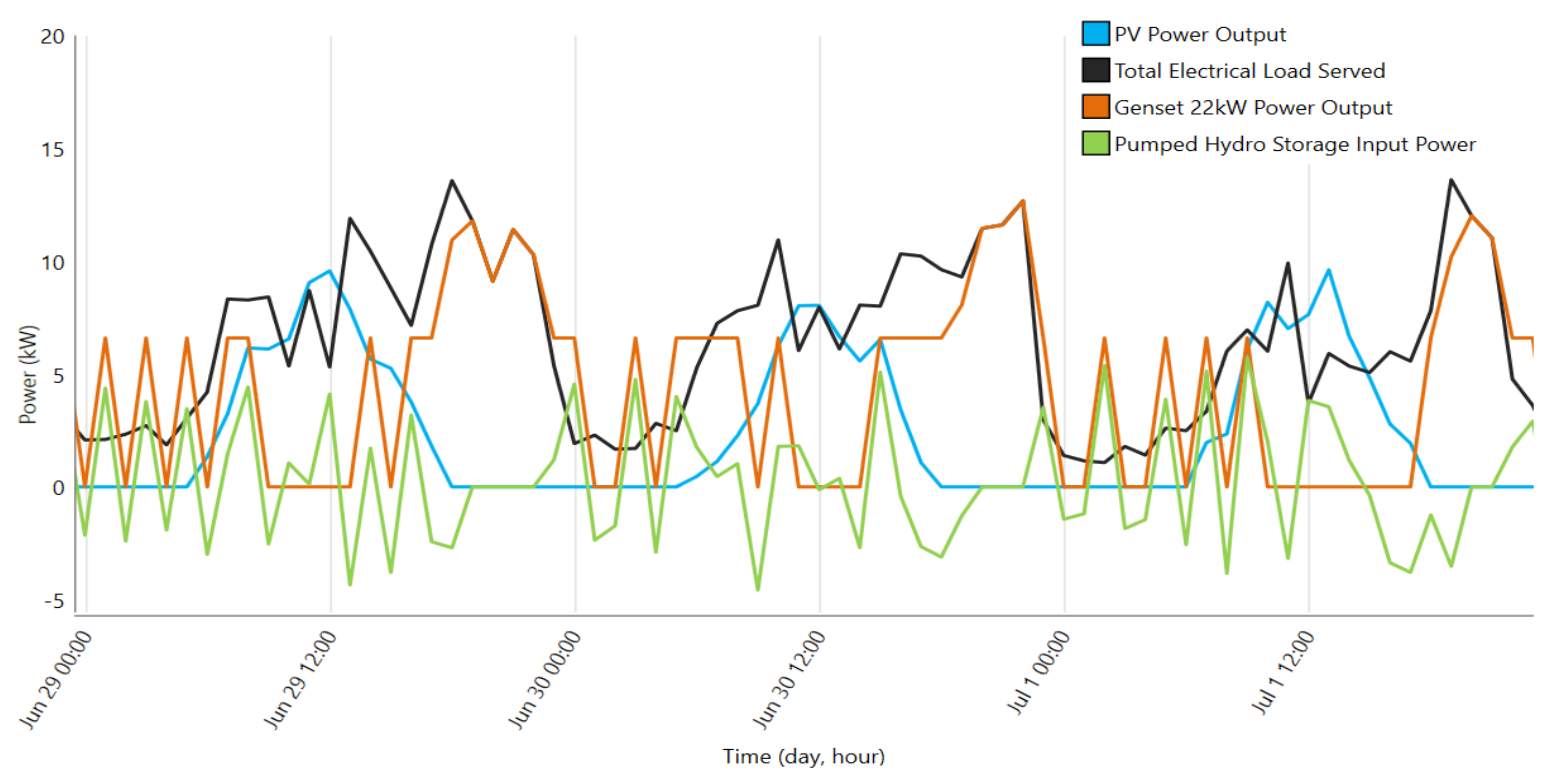

Figure 4. Energy scheduling of the optimal system through three days

\subsection{Economical analysis}

The NPC feasibility follow this rule: if the NPC is negative, then the project is not recommended to be implemented, if the NPC value is positive, then the project is feasible to be realized and if the NPC value is zero, it means that there is no change if the project is still being implemented or not. The payback Period which 
has a shorter period than the life of the project, the investment is feasible to be realized. However, if the payback period has a longer period than the life of the project, the investment is not feasible to be realized.

The first, NPC criteria of IDR. 3,00 B were declared feasible because they had exceeded the criteria of the NPC method where if the NPC was positive, the project was feasible to continue. Second, in the payback period method, it is obtained that the length of time is 10 years 4 months. This result fulfills the criteria because if the payback period is smaller than the project life is declared feasible to continue, the PV system with pumped hydro storage project is planned to last for 25 years. The cost of energy of the system designed is IDR. $2,387 / \mathrm{kWh}$ is lower than the basic cost of providing electricity set by the ministry of energy and mineral resources, which is IDR. 2,538/kWh. However greater than PLN tariff, but this value can be considered for applications in the remote island area. Therefore, the project still feasible to be implemented. Based on Table 5, the project is feasible to be implemented because it has met all economic feasibility criteria of a project.

Table 5. The economic feasibility simulation results

\begin{tabular}{ccc}
\hline Parameters & Result & Conclusion \\
\hline NPC & IDR 3,001,729,000.00 & Feasible to be realized \\
PP & 10 years and 4 months & Feasible to be realized \\
CoE & IDR. 2,387.00/kWh & Not feasible to be realized, but can be considered for the remote islanded area \\
\hline
\end{tabular}

\subsection{Environmental analysis}

Indonesia is committed to reducing greenhouse gas emissions (GHG) by $29 \%$ and $\mathrm{CO}_{2}$ emissions up to 8 million tons by 2030 [29], [30]. The development of renewable hybrid generation is predicted will contribute to reducing GHG as well as $\mathrm{CO}_{2}$ emissions. The emissions (pollutant) of the optimal hybrid system with PV/DG/PHS over one year compared to the base case with only diesel genset is shown in Table 6. The environmental impact of the optimized hybrid system in terms of carbon emissions has been reduced to $23,240 \mathrm{~kg} /$ year compared to the base case of 39,222 kg/year. This is in line with the Indonesian government's targets that by 2025 the installed capacity of the solar power plant will reach $1.0 \mathrm{GW}$ [31].

Table 6. Environment comparison

\begin{tabular}{|c|c|c|c|}
\hline \multirow{2}{*}{ Emissions (Pollutant) } & \multirow{2}{*}{ Unit } & \multicolumn{2}{|c|}{ Quantity } \\
\hline & & Optimized hybrid system & Base case (Diesel Genset) \\
\hline Carbon Dioxide & $\mathrm{kg} / \mathrm{yr}$ & 23,240 & 39,222 \\
\hline Carbon Monoxide & $\mathrm{kg} / \mathrm{yr}$ & 5.62 & 9.49 \\
\hline Unburned Hydrocarbons & $\mathrm{kg} / \mathrm{yr}$ & 0 & 0 \\
\hline Particulate Matter & $\mathrm{kg} / \mathrm{yr}$ & 1.32 & 2.22 \\
\hline Sulfur Dioxide & $\mathrm{kg} / \mathrm{yr}$ & 47.6 & 80.3 \\
\hline Nitrogen Oxides & $\mathrm{kg} / \mathrm{yr}$ & 13.3 & 22.4 \\
\hline
\end{tabular}

\section{CONCLUSION}

The economic feasibility analysis of hybrid PV/wind/diesel with pumped hydro storage for a rural microgrid system has been presented. The simulation test results on the Homer software produce 48 solutions with details of 22 feasible system solutions, and 26 system solutions that are not feasible due to lack of storage capacity. An optimal system has been achieved for the lowest NPC consist of $15 \mathrm{kWp}$ PV modules, 1 unit of 171,44 kWh pumped hydro storage and a solar inverter with a size $25 \mathrm{~kW}$. The use of generation from wind turbine is less profitable for electricity of the Mentawai Islands microgrid system because the wind speed is relatively low. The NPC of PV system with pumped hydro storage is IDR 3,00 B, cost of energy is IDR. 2,387/kWh greater than the basic normal electrical tariff, payback period under the project lifetime. Three parameters of economic feasibility have met the criteria for a project to be built, since the cost of energy for archipelagic areas can be excluded, the project feasible to be implemented. The renewable fraction of this system is $30.1 \%$, hence this proposed system will have the lowest carbon emission. These design and development study result of PV/wind/diesel hybrid system with a water pump storage system are expected to be implemented in other isolated systems spread across Indonesia.

\section{ACKNOWLEDGMENTS}

Acknowledgement is addressed to LPPM Universitas Andalas for supporting research funding with grant number T/5/UN.16.17/PP.Energi-KRP2GB/LPPM/ 2020. 


\section{REFERENCES}

[1] C. K. Nayak, K. Kasturi, M. R. Nayak, and M. R. N. Chinmay K.N., Kumari K, "Economical management of microgrid for optimal participation in electricity market," J. Energy Storage, vol. 21, no. February 2019, pp. 657664., 2019.

[2] M. S. Islami, T. Urmee, and I. N. S. Kumara, "Developing a framework to increase solar photovoltaic microgrid penetration in the tropical region: A case study in Indonesia," Sustain. Energy Technol. Assessments, vol. 47, 2021.

[3] Indonesia: Governmen Regulation 79/2014, "National Energy Policy," Ministry of Energy and Mineral Resources of the Republic of Indonesia, 2014. [Online]. Available: https://jdih.esdm.go.id/index.php/web/result/186/detail.

[4] M. W. D. Utami, A. T. Haryanto, and W. Sutopo, "Consumer perception analysis of electric car vehicle in Indonesia," in 5th International Conference on Industrial, Mechanical Electrical, and Chemical Engineering 2019, ICIMECE 2019, 2020, vol. 2217.

[5] M. J. Hadidian Moghaddam, A. Kalam, S. A. Nowdeh, A. Ahmadi, M. Babanezhad, and S. Saha, "Optimal sizing and energy management of stand-alone hybrid photovoltaic/wind system based on hydrogen storage considering LOEE and LOLE reliability indices using flower pollination algorithm," Renew. Energy, vol. 135, pp. 1412-1434, 2019.

[6] S. Ghazali, R. Putra, and H. Putra, "Online monitoring of grid connected residential photovoltaic system using zigbee and web server," Indones. J. Electr. Eng. Comput. Sci., vol. 7, no. 3, pp. 668-675, 2017.

[7] Syafii and R. Nazir, "Performance and energy saving analysis of grid connected photovoltaic in West Sumatera," Int. J. Power Electron. Drive Syst., vol. 7, no. 4, 2016.

[8] Syafii and K. M. Nor, "Unbalanced active distribution analysis with renewable distributed energy resources," Telkomnika (Telecommunication Comput. Electron. Control., vol. 13, no. 1, 2015.

[9] S. Ashrafi Goudarzi, F. Fazelpour, G. B. Gharehpetian, and M. A. Rosen, "Techno-economic assessment of hybrid renewable resources for a residential building in tehran," Environ. Prog. Sustain. Energy, vol. 38, no. 5, 2019.

[10] H. Mun, B. Moon, S. Park, and Y. Yoon, "A study on the economic feasibility of stand-alone microgrid for carbonfree island in Korea," Energies, vol. 14, no. 7, 2021.

[11] A. Ibnelouad, A. El Kari, H. Ayad, and M. Mjahed, "Improved cooperative artificial neural network-particle swarm optimization approach for solar photovoltaic systems using maximum power point tracking," Int. Trans. Electr. Energy Syst., vol. 30, no. 8, 2020.

[12] M. Ostrowski, "Photovoltaic maximum power point search method using a light sensor," Proceedings Volume 9516, Integrated Optics: Physics and Simulations II; 95160D, 2015, vol. 9516, doi: 10.1117/12.2178714.

[13] I. Serban and C. Marinescu, "Battery energy storage system for frequency support in microgrids and with enhanced control features for uninterruptible supply of local loads," Int. J. Electr. Power Energy Syst., vol. 54, pp. 432-441, 2014.

[14] S. Koohi-Kamali, V. V. Tyagi, N. A. Rahim, N. L. Panwar, and H. Mokhlis, "Emergence of energy storage technologies as the solution for reliable operation of smart power systems: A review," Renew. Sustain. Energy Rev., vol. 25 , pp. $135-165,2013$.

[15] X. Luo et al., "Modelling study, efficiency analysis and optimisation of large-scale Adiabatic Compressed Air Energy Storage systems with low-temperature thermal storage," Appl. Energy, vol. 162, pp. 589-600, 2016.

[16] Z. Tehrani et al., "Large-area printed supercapacitor technology for low-cost domestic green energy storage," Energy, vol. 118, pp. 1313-1321, 2017.

[17] T. Ma, H. Yang, L. Lu, and J. Peng, "Pumped storage-based standalone photovoltaic power generation system: Modeling and techno-economic optimization," Appl. Energy, vol. 137, pp. 649-659, 2015.

[18] T. Kousksou, P. Bruel, A. Jamil, T. El Rhafiki, and Y. Zeraouli, "Energy storage: Applications and challenges," Sol. Energy Mater. Sol. Cells, vol. 120, no. Part A, pp. 59-80, 2014.

[19] O. O. Mengi and I. H. Altas, "A new energy management technique for PV/wind/grid renewable energy system," Int. J. Photoenergy, vol. 2015, no. April, 2015.

[20] E. Dursun and O. Kilic, "Comparative evaluation of different power management strategies of a stand-alone PV/Wind/PEMFC hybrid power system," Int. J. Electr. Power Energy Syst., vol. 34, no. 1, pp. 81-89, 2012

[21] A. A. Khodadoost Arani, G. B. Gharehpetian, and M. Abedi, "Review on Energy Storage Systems Control Methods in Microgrids," Int. J. Electr. Power Energy Syst., vol. 107, no. February, pp. 745-757, 2019.

[22] E. M. Krieger, J. Cannarella, and C. B. Arnold, "A comparison of lead-acid and lithium-based battery behavior and capacity fade in off-grid renewable charging applications," Energy, vol. 60, pp. 492-500, 2013.

[23] T. Ma, H. Yang, and L. Lu, "Feasibility study and economic analysis of pumped hydro storage and battery storage for a renewable energy powered island," Energy Convers. Manag., vol. 79, pp. 387-397, 2014.

[24] S. Hagerman, P. Jaramillo, and M. G. Morgan, "Is rooftop solar PV at socket parity without subsidies?," Energy Policy, vol. 89, pp. 84-94, 2016.

[25] A. Ghazali M. and A. M. Abdul Rahman, "The Performance of Three Different Solar Panels for Solar Electricity Applying Solar Tracking Device under the Malaysian Climate Condition," Energy Environ. Res., vol. 2, no. 1, pp. 235-243, 2012.

[26] L. Wang and C. Singh, "Multicriteria design of hybrid power generation systems based on a modified particle swarm optimization algorithm," IEEE Trans. Energy Convers., vol. 24, no. 1, pp. 163-172, 2009.

[27] I. J. Perez-Arriaga and C. Batlle, "Impacts of intermittent renewables on electricity generation system operation," Econ. Energy Environ. Policy, vol. 1, no. 2, pp. 3-17, 2012.

[28] A. K. Srivastava, A. A. Kumar, and N. N. Schulz, "Impact of distributed generations with energy storage devices on the electric grid," IEEE Syst. J., vol. 6, no. 1, pp. 110-117, 2012.

[29] Arfin and R. D. Lindawati, "Green constitution concept to achieve green Indonesia 2030," Int. J. Adv. Sci.

\footnotetext{
Techno-economic-enviro optimization analysis of diesel/PV/wind with pumped hydro storage for ... (Syafii)
} 
Technol., vol. 29, no. 3 Special Issue, pp. 1251-1256, 2020.

[30] C. Dong, X. Dong, Q. Jiang, K. Dong, and G. Liu, "What is the probability of achieving the carbon dioxide emission targets of the Paris Agreement? Evidence from the top ten emitters," Sci. Total Environ., vol. 622-623, pp. 1294-1303, 2018.

[31] A. N. Sommeng and C. Anditya, "Boosting renewable power generation in Indonesia electricity sector: A policy action by the government," in 3rd International Tropical Renewable Energy Conference "Sustainable Development of Tropical Renewable Energy'”, i-TREC 2018, 2018, vol. 67.

\section{BIOGRAPHIES OF AUTHORS}

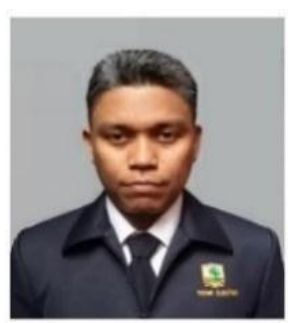

Syafii received a B.Sc degree in electrical engineering from the University of North Sumatera, in 1997 and M.T. degree in electrical engineering from Bandung Institute of Technology, Indonesia, in 2002 and a Ph.D. degree from Universiti Teknologi Malaysia in 2011. He is currently a senior lecturer in the Departement of Electrical Engineering, Universitas Andalas, Indonesia. His research interests are new and renewable energy, smart grid, and power system computation.

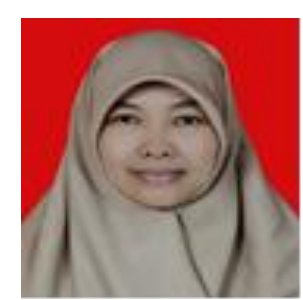

Wati, received B.Sc degree in from Accounting Education IKIP Padang in 1999 and M.Pd. degree in Economic Education from Padang State University, Indonesia, in 2014. Her research interests are economic feasibility study, project management and entrepreneurship.

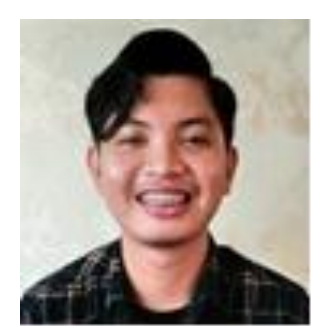

Rahmad Fahreza received B.Sc degree in electrical engineering from Universitas Andalas in 2021. He is currently a research assistant in Departement of Electrical Engineering, Universitas Andalas, Indonesia. His research interests are new and renewable energy and power system analysis. 